\title{
Indeks Desa Zakat Pada Desa Penambangan Kabupaten Sidoarjo 2015-2018
}

\author{
Wildhan Mukhammad ${ }^{1}$, Tony Seno A ji ${ }^{2}$ \\ Universitas Negeri Surabaya \\ Email.wildanmuhammad1144@gmail.com
}

\begin{abstract}
: This study explained the development of zakat-based villages, a method published as a form of response to the less than optimal government programs as well as an alternative in villages development. This study focused on the priority status of the feasibility of a Penambangan Village as an object of research in receiving zakat funds as a form of zakat-based village development. The research method used in this study was a quantitative method, the data used in this study were primary data where the data collection tool used was a questionnaire that has been provided and validated by BAZNAS, and the data processing method used in this study was the Indeks Desa Zakat. The Indeks Desa Zakat (IDZ) is a Process-Oriented-based measuring instrument which not only assess the appropriateness of an object (village, community) in receiving zakat funds, but also evaluate programs that are already running or that have been carried out. IDZ was a derivative of Zakat Community Development $(Z C D)$, that acts as an empowerment program for productive zakat funds. There were nineteen sample used in this study, consist of all RT (rukun tetangga) in Penambangan Village. The results of this study indicated that Penambangan Village has good condition so that so that it is less referred to be assisted through zakat fund.
\end{abstract}

Keywords $\quad$ : Zakat, IDZ, ZCD, BAZNAS

\section{Latar Belakang}

Akhir-akhir ini dunia digemparkan dengan adanya perang dagang berskala global antar negara raksasa yakni Amerika dan China, kedua negara tersebut saling balas dalam menaikan tarif barang impor. Dampaknya te tu tidak hanya dirasakan, oleh kedua negara utama yang berperang tarif barang impor tapi seluruh negara yang ada didunia juga merasakan dampaknya. Hal ini bisa dibuktikan dengan respon cepat dari International Monetery Fund sebagai lembaga kredibel yang mengkaji tentang ekonomi global atau dunia, yaitu merespon dengan cara menurunkan peningkatan pertumbuhan ekonomi global yang sebelumnya bisa meningkat mencapai 3,4\% diturunkan menjadi 3,2\% saja. Perlambatan ekonomi global ini tentu akan meresahkan semua negara khususnya bagi negara miskin dan berkembang yang terbagi fokus karena juga harus berjuang melawan tingkat kemiskinan yang ada dinegara masing-masing (Katadata.com, 2019).

Kemiskinan adalah keadaan serba kurang terutama kebutuhan pokok atau primer yang tidak terpenuhi seperti makanan, tempat berlindung, pendidikan, dan kesehatan. Undang-Undang Dasar (UUD) 1945 memaparkan bahwa tujuan berdirinya suatu negara adalah untuk melindungi bangsa, menyejahterakan, mencerdaskan kehidupan bangsa, menjaga kemerdekaan, perdamaian, dan keadilan sosial bagi rakyatnya. Oleh karena itu dapat disimpulkan bahwasannya kemiskinan adalah problem yang harus diseleseikan oleh suatu negara. Kemiskinan dipengaruhi beberapa faktor namun yang paling banyak ditemui yaitu adanya ketimpangan antara penduduk yang berpendapatan tinggi dan rendah hal ini banyak dijumpai di negara-negara berkembang.

Indonesia adalah negara yang ada di Asia dan termasuk negara berkembang jika melihat fenomena dan fakta yang ada. Namun pada akhir-akhir ini Amerika dan World 
Trade Organization (WTO) mencoret nama Indonesia sebagai negara berkembang dan menjadi negara maju. Indonesia memiliki penduduk yang banyak hingga mencapai 264 juta jiwa namun sepuluh persen dari total penduduk Indonesia masih dikategorikan di bawah garis kemiskinan yakni sekitar 25,14 juta jiwa (BPS, 2020). Indonesia merupakan negara kepulauan sehingga ada banyak titik daerah yang susah untuk dijangkau, oleh karena itu tidak sedikit orang miskin yang terdapat di Indonesia. Adapun lembaga yang mempunyai wewenang dalam memberantas kemiskinan, Indonesia sudah mempunyai semua. Dibidang pembangunan ada Badan Perencanaan Pembangunan Nasional (BAPPENAS), Kementrian Kebudayaan dan Pendidikan (KEMENDIKBUD), Badan Amil Zakat Nasional (BAZNAS).

BAZNAS ialah badan resmi tunggal didirikan oleh pemerintah dan tidak ada yang lain, berlandaskan pada ketetapan yang sudah ditetapkan oleh Presiden Republik Indonesia (RI) No. 8 tahun 2001 menghimpun dan mendistribusikan zakat, infaq, dan sedekah (ZIS) pada skala nasional merupakan tanggung jawab utama dan pertama sejak berdirinya BAZNAS. Potensi zakat di Indonesia memang sangat besar jika dilihat dari besarnya persentase penduduk yang beragama Islam, karena semakin banyak orang yang beragama islam maka akan semakin banyak juga yang akan membayar zakat. Namun hal ini tidak sesuai teorinya, karena banyak masyarakat di Indonesia yang kurang menyadari betapa pentingnya atau urgensi dalam membayar zakat. Ada juga kasus lain seperti ada orang yang paham akan urgensi zakat tetapi kurangnya kecakapan dalam membayar zakat terutama pemahaman mengenai zakat maal, sehingga banyak yang mengabaikan zakat maal (maghfiroh, 2017). Oleh karena itu BAZNAS selaku lembaga resmi pengelola dana zakat dituntut agar lebih dalam lagi dalam mensosialisasikan mengenai urgensi zakat yang juga merupakan rukun islam walaupun hasil kinerja BAZNAS dalam beberapa tahun terakhir tidak pernah mengalami stagnan atau terus mengalami kenaikan penghimpunan total ZIS. Sebagaimana dari fungsi berdirinya BAZNAS selain menghimpun juga bertanggung jawab dalam menyalurkan dana ZIS sampai ke tangan orang yang tepat.

BAZNAS secara garis besar memiliki dua program dalam menyalurkan dana ZIS yakni penyaluran yang bersifat Konsumtif dan Produktif. Dalam penyaluran dana ZIS Produktif BAZNAS memiliki program yang bernama Zakat Comunnity Development (ZCD) yang merupakan program pengembangan masyarakat melalui dana zakat yang sesuai dengan namanya Community Development yang bertugas melalui program-program pembangunannya untuk mempercepat terwujudnya kesejahteraan umum. Keadaan ini sangat sinkron sebagaimana pembukaan Undang-Undang Dasar Negara Republik Indonesia 1945 (UUD 1945) alinea yang ke-empat. Program-program pembangunan yang telah diselenggarakan oleh pemerintah Indonesia selama ini belum menemukan formula pas, karena belum maksimalnya dampak dari program yang dijalankan. Hal ini bisa dilihat dengan dua indikator yaitu yang pertama jumlah penduduk miskin yang masih tinggi yaitu $9,41 \%$ (BPS) dan indeks pembangunan manusia yang masih rendah yaitu 0,707 Indonesia menempati posisi 111 dari total 189 negara yang ada di dunia (UNDP, 2017). Melihat hal ini Pusat Kajian Strategi (PUSKAS BAZNAS) mengembangkan suatu penelitian agar dapat mengkaji lebih dalam untuk mengatasi masalah dan juga untuk membantu mengembangkan suatu desa agar berkembang lebih efisien yaitu melalui alat untuk penelitian yakni Indeks Desa Zakat (IDZ).

Indeks Desa Zakat (IDZ) secara umumnya digambarkan sebagai alat ukur penelitian yang dipakai untuk menilai suatu keadaan desa yang diteliti agar peneliti mengetahui apakah desa tersebut layak diberi dana zakat atau tidak. Selain untuk mengukur kelayakan suatu desa, IDZ juga bisa digunakan untuk memonitoring desa yang sudah diteliti. Artinya IDZ merupakan alat ukur yang berbasis process oriented yang mampu dipakai oleh Organiasasi Pengelola Zakat guna sebagai alat memonitoring program yang sudah 
dijalankan. Sehingga IDZ bisa menjadi bahan referensi bagi setiap Organiasasi Pengelola Zakat yang bakal atau tengah melangsungkan program pemberdayaan yang berbasis desa supaya lebih akurat tidak salah sasaran dan lebih efisien dalam pemberdayaannya (BAZNAS, 2017).

Badan Perencanaan Pembangunan Daerah (BAPPEDA) Sidoarjo menerbitkan penilaian program pembangunan berjalan Kota Sidoarjo pada tahun 2018. Bahwasanya Kota Sidoarjo terbilang sukses dalam membangun kota Sidaorjo, karena berdasarkan data kemiskinan Propinsi Jawa Timur Kota Sidoarjo masuk ke dalam sepuluh besar yang tingkat kemiskinannya memiliki persentase paling sedikit. Namun yang menjadi catatan penting bahwa kemiskinan di Kota Sidoarjo memiliki karakteristik yang unik karena orang yang miskin cenderung banyak ditemukan didaerah tertentu seperti Prambon, Tarik, Balongbendo, Jabon, Krembung, dan Tulangan (Munari, 2018). Penyaluran zakat yang efektif sudah bisa dipastikan besar atau kecil akan berperan penting dalam memberantas kemiskinan, terlebih jika disuatu daerah memiliki potensi lebih untuk mengurangi kemiskinan tersebut. Seperti jumlah masyarakat muslim disuatu daerah yang mempunyai jumlah yang dominan, memiliki kecakapan dan kesadaran akan pentingnya barzakat dan tentunya terbebas dari jurang kemiskinan. Berdasarkan data yang ada persentase orang yang beragama islam di Sidoarjo mencapai $95 \%$ dari total penduduk Sidoarjo, terlebih lagi 14.818 jiwa merupakan penduduk yang bekerja sebagai Pegawai Negeri Sipil (PNS) (BPS, 2018). Tentu hal ini menjadi modal yang besar guna untuk mengentas kemiskinan yang ada di Kabupaten Sidoarjo, disisi lain tentu harus diimbangi dengan pengelolaan zakat yang efisien dan efektif. Selama ini pengelolaan zakat yang ada di Sidoarjo terbilang kurang baik, dapat dilihat dari penyalurannya yang terfokus pada konsumtif, demikian akan membuat pengelolaan zakat menjadi tidak optimal. hal ini dapat dilihat pada program-program yang sudah berlaksana pada BAZNAS Sidoarjo.

Pengelolaan zakat yang optimal tentu dalam program harus dibarengi dengan instrumen-instrumen pendukung untuk memonitor dana yang sudah disalurkan sehingga bisa dievaluasi jika ada kesalahan. Seperti halnya program ZCD yang mempunyai instrumen IDZ sebagai upaya untuk memonitori dana pengembangan desa, karena setiap desa memiliki karakteristik berbeda-beda dan tentunya harus diperlakukan berbeda juga dalam penyeleseianya. Seperti halnya pada penelitian Nilda dkk (2019) di Sukaraja, mempunyai kendala kurang terstrukturnya pengelolaan hasil kebun dan sawah, kemudian dari Farikhatushollikah dkk (2018) di Desa Bendono yang memiliki kendala utama masalah ekonomi dikarenakan kurang adanya pasar terpusat untuk berjualan dan kemudian dari Rahman Saleh dkk (2018) di Desa Bringinsari yang memiliki kendala dalam penjualan jambu biji dikarenakan tengkulak yang tidak pasti. Oleh karena itu progam IDZ perlu terus untuk dilanjutkan ke desa-desa yang ada di Indonesia, sehingga permasalahanpermasalahan yang membuat tiap desa stagnan untuk berkembang bisa untuk terseleseikan. Dalam hal ini juga berlaku pada Desa Penambangan yang dijadikan objek studi dikarenakan mempunyai potensi yang besar untuk berkembang dikarenakan mempunyai lahan persawahanya yang luas. Adapun yang membedakan dengan penelitian sebelumnya adalah dari pengambilan sampel yang dipilih, penelitian sebelumnya notabene sampel dipakai adalah perangkat desa sedangkan dalam studi ini yang dipilih adalah semua ketua RT sehingga hasilnya akan diperoleh bisa lebih maksimal karena narasumber lebih paham daerah yang dipimpin. 


\section{Teori dan Metode}

\subsection{Pendayagunaan zakat}

Kelompok fakir miskin selama ini selalu identik dengan beban dan tidak memiliki potensi yang bisa dikembangkan, padahal hal itu tidaklah benar. Potensi fakir miskin tidak berkembang karena ada yang mengikat kebebasan mereka dalam berkreasi dan mengembangkan potensinya terutama faktor ekonomi yang paling mengikat. Menjawab permasalahan inilah seharusnya dana zakat bisa berperan aktif dalam mengembangkan potensi dari masyarakat fakir miskin, karena zakat merupakan elemen yang sudah pasti pendayagunaanya yaitu kedelapan ashnaf walaupun begitu yang paling dipreferensikan adalah fakir dan miskin. Menurut Mintarti dalam karyanya memaparkan bahwa dalam upaya memajukan sosial dan ekonomi bagi kelompok fakir miskin memiliki keselarasan tujuan dengan pemberdayaan kelompok berasaskan zakat, karena yang berpartisipasi dan berinisiatif aktif adalah kelompok itu sendiri (Mintarti, 2011). Adapun tujuan dari pendayagunaan dana zakat melalui OPZ menurut Suprayitno sebagai berikut. Pertama, memperbaiki taraf hidup, karena dalam pendayagunaan dana zakat yang menjadi fokus utama adalah orang yang berada di bawah garis kemiskinan (fakir dan miskin). Kedua, pendidikan dan Beasiswa, karena berdasarkan penelitian yang ada bahwa pendidikan adalah pondasi awal untuk mengentaskan kemiskinan. Ketiga, mengatasi masalah pengangguran, dana zakat juga bisa berperan aktif dalam membuka lapangan pekerjaan dengan cara pemberian pembinaan, modal usaha, serta pendampingan. Keempat, program pelayanan kesehatan, bisa dalam bentuk pendirian poliklinik kecil, membantu menanggung pembiayaan atau bisa dengan fasilitas ambulance gratis. Kelima, panti Asuhan, sebagai upaya utama untuk menanggulangi anak-anak terlantar

\subsection{Zakat Community Development}

Zakat Community Development (ZCD) ialah bentuk pengembangan masyarakat atau komunitas melalui penggabungan aspek sosial dan aspek ekonomi yang sumber modal pendanaanya bersumber dari zakat, infak, dan sedekah. Hingga terciptalah masyarakat yang makmur, sentosa, tentram dan tentunya swasembada sebagai tujuan utamanya. Program ZCD ada enam prinsip utama yang harus ada disetiap konsep dan tahapan eksekusi pengaplikasian program serta terpatri dalam setiap diri pelaksana dan peserta acara itu sendiri. Enam prinsip itu adalah berbasis kelompok, syari'ah, berperan aktif, kemaslahatan, kontinu, dan bersinergi (BAZNAS,2013).

\subsection{Indeks Desa Zakat}

Indeks Desa Zakat alias biasanya disingkat dengan istilah IDZ ialah sebuah alat ukur yang dipakai untuk menilai keadaan sebuah desa sehingga bisa dinyatakan layak atau tidaknya untuk didukung dalam pengembangan desa menggunakan dana zakat. IDZ tidak hanya bisa digunakan dalam menentukan kelayakan suatu desa namun IDZ juga bisa digunakan sebagai alat untuk mengevaluasi suatu program pengembangan desa yang sudah berjalan karena IDZ berbasis process oriented sebagaimana sudah disebutkan diawal. Oleh sebab itu IDZ tidak hanya digunakan sebagai penguji kelayakan tapi juga bisa digunakan sebagai alat untuk memonitoring atau mengevaluasi atas proses pengelolaan dana zakat yang sudah disalurkan. Program alat ukur ini dikeluarkan pertama kali pada tahun 2017 dan diresmikan oleh Pusat Kajian Strategi BAZNAS. IDZ dibentuk dari beberapa 
komponen, ada lima yakni Ekonomi, Kesehatan, Pendidikan, Sosial Kemanusiaan, dan dakwah. Adapun untuk mengetahui suatu objek penelitian layak atau tidak layak dalam menerima dana zakat tergantung dari berapa nilai akhir yang didapat, karena dalam studi ini murni mengacu pada pedoman yang suda diterbitkan oleh pihak BAZNAS.

\subsection{Metode penelitian}

Studi ini dilakukan menggunakan metode kuantitatif dan data yang dipakai adalah data primer, langsung turun kelapangan untuk pengambilan data menggunakan kuisioner yang sudah diterbitkan oleh BAZNAS. Menggunakan metode kuantitatif dikarenakan ingin mengetahui kelayakan Desa Penambangan yang disini sebagai objek studi dalam menerima dana zakat sebagai bentuk pengembangan desa yang dilakukan oleh BAZNAS.

Data yang dipakai dalam studi ini adalah data primer, langsung turun ke lapangan untuk pengambilan data. Sedangkan sampel yang dipakai dalam studi ini ialah semua RT yang ada di Desa Penambangan yang berjumlah 19 RT. Kemudian dari data diperoleh akan mendapatkan skor 1-5 dan kemudian data yang sudah terkumpul nantinya akan dihitung menggunakan Multy-stage Weight Index digunakan untuk mempresentasikan hasil perhitungan IDZ. Kemudian data yang didapat akan diberikan bobot dan skor sesuai dengan indikator yang telah ditentukan dalam likert scale.

$$
\begin{aligned}
& \text { Ix =(VSx-Smin }) /(\text { Smax-Smin }) \\
& \text { Diketahui, } \\
& \begin{array}{ll}
\text { Ix } & \text { : Indikator pada Variabel } \\
\text { VSx } & \text { : Nilai skor aktual pada pengukuran variabel } \\
\text { Smax } & \text { : Skor maksimal } \\
\text { Smin } & \text { : Skor minimal }
\end{array}
\end{aligned}
$$

\begin{tabular}{|c|c|c|c|}
\hline Dimensi IDZ & Bobot Dimensi & Variabel & Bobot Variabel \\
\hline \multirow{5}{*}{ Ekonomi } & \multirow{5}{*}{0,25} & $\begin{array}{l}\text { Kegiatan } \\
\text { produktif }\end{array}$ & 0,28 \\
\hline & & Pusat Perdagangan Desa & 0,24 \\
\hline & & $\begin{array}{l}\text { Akses Transpor tasi dan } \\
\text { jasa pengiriman }\end{array}$ & 0,22 \\
\hline & & $\begin{array}{ll}\text { Akses } & \text { Lembaga } \\
\text { Keuangan } & \end{array}$ & 0,26 \\
\hline & & Total Bobot Variabel & 1.00 \\
\hline \multirow{4}{*}{ Kesehatan } & \multirow{4}{*}{0,16} & Kesehatan Masyarakat & 0,41 \\
\hline & & Pelayanan Kesehatan & 0,36 \\
\hline & & Jaminan Kesehatan & 0,23 \\
\hline & & Total Bobot Variabel & 1.00 \\
\hline \multirow{3}{*}{ Pendidikan } & \multirow{3}{*}{0,20} & Tingkat Pendidikan & 0,50 \\
\hline & & Fasilitas Pendidikan & 0,50 \\
\hline & & Total Bobot Variabel & 1.00 \\
\hline
\end{tabular}

Selanjutnya dari hasil yang didapat akan dikalikan dengan bobot masing-masing indikator dan variabel dengan bertahap menggunakan rumus Indeks Desa Zakat (IDZ) ;

Tabel 1 : Pembobotan Variabel dan Dimensi IDZ 


\begin{tabular}{|c|c|c|c|}
\hline \multirow{4}{*}{$\begin{array}{l}\text { Sosial dan } \\
\text { Kemanusian }\end{array}$} & \multirow{4}{*}{0,17} & $\begin{array}{l}\text { Sarana Ruang } \\
\text { Komunikasi Terbuka }\end{array}$ & 0,36 \\
\hline & & $\begin{array}{lr}\text { Infrastruktur } & \text { Listrik, } \\
\text { komunikasi } & \text { dan } \\
\text { Informasi } & \end{array}$ & 0,43 \\
\hline & & Mitigasi bencana alam & 0,21 \\
\hline & & Total Bobot Variabel & 1.00 \\
\hline \multirow{4}{*}{ Dakwah } & \multirow{4}{*}{0,22} & $\begin{array}{l}\text { Tersedia Sarana dan } \\
\text { Pendamping }\end{array}$ & 0,33 \\
\hline & & $\begin{array}{l}\text { Tingkat Pengetahuan } \\
\text { Agama }\end{array}$ & 0,30 \\
\hline & & $\begin{array}{l}\text { Tingkat Keaktifan dan } \\
\text { Partisipasi }\end{array}$ & 0,37 \\
\hline & & Total Bobot Variabel & 1.00 \\
\hline
\end{tabular}

Kemudian hasil perhitungan dari tiap variabel akan dijumlahkan kemudian akan dikalikan dengan rumus IDZ sebagai berikut;

$\mathrm{IDZ}=(\mathrm{X} 1 e k+\mathrm{X} 2 k s+\mathrm{X} 3 p e+\mathrm{X} 4 k e+\mathrm{X} 5 d a)$

Dimana,

Indeks Desa Zakat X1,..,X5 : bobot penilaian

ek : Ekonomi

ks : Kesehatan

pe : Pendidikan

ke : Kemanusiaan

da : Dakwah

Terakhir nilai IDZ didapat yaitu berkisaran antara 0-1 nantinya akan dikategorikan dengan score range sebagai berikut;

Tabel 2 : Kategori Hasil

\begin{tabular}{|c|c|c|}
\hline Score Range & Kategori & Intepretasi \\
\hline $0,00-0,20$ & Tidak baik & Sangat Dipreferensikan Dibantu \\
\hline $0,21-0,40$ & Kurang baik & Dipreferensikan Dibantu \\
\hline $0,41-0,60$ & Cukup baik & Dipertimbangkan \\
\hline $0,61-0,80$ & Baik & Kurang Dipreferensikan \\
\hline $0,81-1,00$ & Sangat baik & Tidak Dipreferensikan \\
\hline
\end{tabular}

\section{Hasil dan Pembahasan}

\subsection{Hasil analisis data}

Dalam studi ini tujuan pengukuran Indeks Desa Zakat (IDZ) ini adalah untuk mengetahui kelayakan desa Penambangan dalam menerima pengembangan desa menggunakan dana zakat. Indeks Desa Zakat mempunyai parameter tersendiri dalam 
menentukan kelayakan suatu desa atau objek dalam menerima dana zakat, ada lima dimensi yaitu ekonomi, pendidikan, kesehatan, sosial kemanusiaan, dan dakwah. Setiap dimensi memiliki variabel dan indikator dan masing-masing memiliki bobot yang dijadikan sebagai parameter perhitungan. Berdasarkan keseluruhan hasil pengukuran yang didapat, desa Penambangan memperoleh nilai IDZ sebesar 0,651. Untuk menjelaskan dari mana nilai akhir yang sudah didapat, brikut adalah penjelasannya dimulai dari tiap variabelnya hingga menemukan skor IDZ.

\section{Indeks Dimensi Ekonomi}

Nilai indeks ekonomi didapatkan dengan cara mengalikan hasil dari keluaran perkalian antara poin indikator dan bobot indikator kemudian dikalikan dengan bobot variabel masing-masing. Dimensi ini memiliki bobot terbesar dalam menentukan nilai IDZ, dikarenakan bobot dari dimensi ekonomi sebesar 0,25 seperempat dari total pembobotan IDZ. Berikut adalah perhitungannya :

$$
\begin{aligned}
& \mathrm{IDE}=0,28(\mathrm{x} 1)+0,24(\mathrm{x} 2)+0,22(\mathrm{x} 3)+0,26(\mathrm{x} 4) \\
& \mathrm{IDE}=0,28(0,24)+0,24(0,42)+0,22(0,41)+0,26(0,25) \\
& \mathrm{IDE}=0,32
\end{aligned}
$$

\begin{tabular}{|c|c|c|c|c|}
\hline Variabel & Bobot Variabel & $\begin{array}{c}\text { Indeks } \\
\text { Variabel }\end{array}$ & Keterangan & Intepretasi \\
\hline $\begin{array}{l}\text { Kegiatan } \\
\text { Ekonomi } \\
\text { Produktif }\end{array}$ & 0,28 & 0,24 & $\begin{array}{c}\text { Kurang } \\
\text { Baik }\end{array}$ & $\begin{array}{l}\text { Dipreferensikan } \\
\text { dibantu }\end{array}$ \\
\hline $\begin{array}{l}\text { Pusat } \\
\text { Perdagangan } \\
\text { Desa }\end{array}$ & 0,24 & 0,42 & Tidak Baik & $\begin{array}{l}\text { Sangat } \\
\text { Dipreferensikan } \\
\text { Dibantu }\end{array}$ \\
\hline $\begin{array}{l}\text { Akses } \\
\text { Transportasi } \\
\text { dan Jasa } \\
\text { Pengiriman }\end{array}$ & 0,22 & 0,41 & Cukup Baik & dipertimbangkan \\
\hline $\begin{array}{l}\text { Akses Lembaga } \\
\text { Keuangan }\end{array}$ & 0,26 & 0,25 & $\begin{array}{c}\text { Kurang } \\
\text { Baik }\end{array}$ & $\begin{array}{l}\text { Dipreferensikan } \\
\text { Dibantu }\end{array}$ \\
\hline
\end{tabular}

Tabel 3 : Nilai Indek Variabel Dimensi Ekonomi

Tabel di atas merupakan gambaran nilai yang didapat dari setiap variabel yang ada pada dimensi ekonomi, sebagaimana yang sudah dipaparkan pada hasil analisis data dimensi ekonomi mendapat nilai terendah jika dibandingkan dengan dimensi yang lainnya. Faktor yang paling menyebabkan dimensi ekonomi terendah adalah karena rendahnya kegiatan ekonomi produktif dan rendahnya jasa pengiriman barang. Adapun nilai indeks pusat perdagangan desa memperoleh nilai terendah dikarenakan pasar yang tersedia disuatu desa memang hanya satu dan minimnya jasa pengiriman barang.

\section{Indeks Dimensi Kesehatan}

Dimensi ini memberikan bobot terkecil dalam menentukan nilai IDZ, dengan bobot sebesar 0,16. Setelah melalui proses perhitungan didapat nilai dimensi kesehatan sebesar 0,81. Nilai ini menunjukan bahwa kesehatan yang ada di desa Penambangan sangat baik. 
Terdapat tiga variabel dalam dimensi ini yaitu 1) kesehatan masyarakat 2) Pelayanan Kesehatan 3) jaminan kesehatan. Berikut adalah perhitungannya :

$$
\begin{aligned}
& \mathrm{IDK}=0,41(\mathrm{X} 1)+0,36(\mathrm{X} 2)+0,23(\mathrm{X} 3) \\
& \mathrm{IDK}=0,41(0,96)+0,36(0,53)+0,23(1) \\
& \mathrm{IDK}=0,81
\end{aligned}
$$

Tabel 4 : Nilai Indek Variabel Dimensi Kesehatan

\begin{tabular}{|lcccl|}
\hline \multicolumn{1}{|c}{ Variabel } & $\begin{array}{c}\text { Bobot } \\
\text { Variabel }\end{array}$ & $\begin{array}{c}\text { Indeks } \\
\text { Variabel }\end{array}$ & Keterangan & \multicolumn{1}{c|}{ Intepretasi } \\
\hline Kesehatan Masyarakat & 0,41 & 0,96 & Baik & $\begin{array}{l}\text { Kurang } \\
\text { Dipreferensikan } \\
\text { Dibantu }\end{array}$ \\
\hline Pelayanan kesehatan & 0,36 & 0,53 & Cukup Baik & Dipertimbangkan \\
\hline Jaminan kesehatan & 0,23 & 1 & Sangat Baik & $\begin{array}{l}\text { Tidak Dipreferensikan } \\
\text { Dibantu }\end{array}$ \\
\hline
\end{tabular}

Berdasarkan tabel, secara umum rumah warga mayoritas sudah layak huni dan mereka pun sudah menggunakan akses air bersih yang baik karena sudah bisa digunakan untuk masak, mandi dan air minum. Pelayanan kesehatan di desa ini cukup baik karena adanya layanan kesehatan yang rutin ada tiap dua pekan disetiap RWnya. Sedangkan untuk variabel jaminan kesehatan sudah sangat baik karena mayoritas bekerja dipabrik jadi memiliki jaminan kesehatan dari pabrik.

\section{Indeks Dimensi Pendidikan}

Variabel yang diukur dalam membentuk dimensi ini ada dua yaitu ada tingkat pendidikan dan litaratur serta fasilitas pendidikan. Berdasarkan nilai bobot yang sudah ditentukan, dimensi pendidikan memiliki bobot 0,22 dalam menentukan nilai IDZ, berikut adalah perhitungannya :

$$
\begin{aligned}
& \mathrm{IDP}=0,50(\mathrm{X} 1)+0,50(\mathrm{X} 2) \\
& \mathrm{IDP}=0,50(0,81)+0,50(0,66) \\
& \mathrm{IDP}=0,74
\end{aligned}
$$

Tabel 5 : Nilai Indek Variabel Dimensi Pendidikan

\begin{tabular}{|lcccl|}
\hline \multicolumn{1}{|c}{ Variabel } & Bobot & $\begin{array}{c}\text { Indeks } \\
\text { Variabel }\end{array}$ & Keterangan & \multicolumn{1}{c|}{ Intepretasi } \\
\hline Pendidikan Masyarakat & 0,50 & 0,81 & Baik & $\begin{array}{l}\text { Kurang } \\
\text { Dipreferensikan }\end{array}$ \\
\hline $\begin{array}{l}\text { Literatur dan Sarana } \\
\text { Pendidikan }\end{array}$ & 0,50 & 0,66 & Kurang baik & $\begin{array}{l}\text { Dipreferensikan } \\
\text { dibantu }\end{array}$ \\
\hline
\end{tabular}

Berdasarkan tabel secara umum tingkat pendidikan masyarakat mayoritas sudah sesuai anjuran pemerintah yaitu dua belas tahun wajib belajar. Namun terkendala divariabel literatur dan sarananya karena tidak adanya sarana dan literatur untuk menunjang pendidikan masyarakat desa. 


\section{Indeks Dimensi Sosial dan Kemanusiaan}

Pembobotan dimensi sosial dan kemanusiaan dalam menentukan nilai IDZ mendapatkan proporsi sebesar 0,17 . Nilai Indeks dimensi ini yaitu 0,55 yang berarti dalam kondisi baik dan kurang dipreferensikan. Terdapat tiga variabel dalam dimensi ini yang akan dibahas. Untuk memperjelas berikut adalah perhitungannya :

$$
\begin{aligned}
& \text { IDSK }=0,36(X 1)+0,43(X 2)+0,21(X 3) \\
& \text { IDSK }=0,36(0,42)+0,43(0,94)+0,21(0) \\
& \text { IDSK }=0,55
\end{aligned}
$$

\begin{tabular}{|c|c|c|c|c|}
\hline Variabel & $\begin{array}{c}\text { Bobot } \\
\text { Variabel }\end{array}$ & $\begin{array}{c}\text { Indeks } \\
\text { Variabel }\end{array}$ & Keterangan & Intepretasi \\
\hline $\begin{array}{l}\text { Sarana Ruang } \\
\text { Interaksi Terbuka } \\
\text { Masyarakat }\end{array}$ & 0,36 & 0,42 & Cukup Baik & Dipertimbangkan \\
\hline $\begin{array}{l}\text { Inf rastruktur } \\
\text { Listrik, Komunikasi } \\
\text { dan Informasi }\end{array}$ & 0,43 & 0,94 & sangat Baik & $\begin{array}{c}\text { Tidak } \\
\text { Dipertimbangkan }\end{array}$ \\
\hline $\begin{array}{ll}\text { Mitigasi } & \text { Bencana } \\
\text { alam } & \\
\end{array}$ & 0,21 & 0 & Baik & $\begin{array}{c}\text { Kurang } \\
\text { Dipreferensikan }\end{array}$ \\
\hline
\end{tabular}

Tabel 6 : Nilai Indek Variabel Dimensi Sosial dan Kemanusiaan

Berdasarkan tabel kondisi sosial dan kemanusiaan desa Penambangan secara umum sudah baik namun yang menjadi kendala ada pada variabel ketiga yaitu mitigasi bencana alam, dikarenakan kebanyakan ketua RT tidak mengetahui adanya sistem penanggulangan hanya ada tabung pemadam kebakaran dibalai desa. Kalaupun ada informasi yang perlu disampaikan mengenai bencana, cara menginformasikannya masih tradisional yaitu menggunakan TOA keliling menggunakan mobil pick up.

\section{Indeks Dimensi Dakwah}

Dalam menentukan IDZ pada dimensi ini memiliki bobot yang terbilang besar, yakni 0,22 . Nilai Indeks dimensi dakwah yaitu 0,83 nilai tersebut menunjukan bahwa kondisi spriritual penduduk desa dalam kondisi baik. Terdapat tiga variabel dalam dimensi ini yaitu 1) adanya pendamping keagamaan 2) tingkat pengetahuan agama masyarakat 3) tingkat keaktifan. Berikut adalah perhitungannya :

$$
\begin{aligned}
& \mathrm{IDD}=0,33(\mathrm{X} 1)+0,30(\mathrm{X} 2)+0,37(\mathrm{X} 3) \\
& \mathrm{IDD}=0,33(0,65)+0,30(0,95)+0,37(0,88) \\
& \mathrm{IDD}=0,83
\end{aligned}
$$

Tabel 7 : Nilai Indek Variabel Dimensi Dakwah

\begin{tabular}{|lcccc|}
\hline \multicolumn{1}{|c}{ Variabel } & $\begin{array}{c}\text { Bobot } \\
\text { Variabel }\end{array}$ & $\begin{array}{c}\text { Indeks } \\
\text { Variabel }\end{array}$ & Keterangan & Intepretasi \\
\hline $\begin{array}{l}\text { Tersedianya Sarana } \\
\text { Pendamping } \\
\text { Keagamaan }\end{array}$ & 0,33 & 0,65 & Cukup Baik & Dipertimbangkan \\
\hline $\begin{array}{l}\text { Tingkat Pengetahuan } \\
\text { Agama }\end{array}$ & 0,30 & 0,95 & sangat Baik & Tidak Dipertimbangkan \\
\hline
\end{tabular}




\begin{tabular}{|lrllll|}
\hline $\begin{array}{l}\text { Tingkat } \\
\begin{array}{l}\text { Keagamaan } \\
\text { Partisipasi }\end{array}\end{array}$ & $\begin{array}{r}\text { Aktifitas } \\
\text { dan }\end{array}$ & 0,37 & 0,88 & Baik & Kurang Dipreferensikan \\
\hline
\end{tabular}

Berdasarkan tabel menunjukan bahwa secara umum kondisi baik dimulai dari sarana pendamping di desa yang mendapatkan nilai 0,65 yang berarti baik. Kemudian tingkat pengetahuan agama yang mendapatkan nilai 0,95 yang berarti dalam kondisi sangat baik dikarenakan pada jenjang anak SD-SMP kebanyakan orang tua mewajibkan anaknya mengikuti TPQ dimasjid terdekat. Kemudian variabel ketiga mendapatkan nilai 0,88 yang dalam kondisi sangat baik dikarenakan selalu ada pengajian rutin tiap RT setidaknya sepekan dua kali.

\section{Indeks Desa Zakat}

Indeks Desa Zakat (IDZ) merupakan hasil dari rangkaian penjumlahan dari lima variabel yang ada. Pertama hasil dari variabel dikalikan dengan bobot dari masing masing variabel yang sudah ditetapkan, kemudian dijumlahkan semua dari lima variabel tersebut maka hasil yang keluar adalah IDZ. Untuk mengetahui gambaran perhitungan IDZ sebagai berikut :

$$
\begin{aligned}
& \mathrm{IDZ}=0,25 e k+0,16 k s+0,20 p e+0,17 k e+0,22 d a \\
& \mathrm{IDZ}=0,25(\mathrm{O}, 32)+0,16(0,81)+0,20(0,74)+0,17(0,55)+0,22(0,83) \\
& \mathrm{IDZ}=0,65
\end{aligned}
$$

\subsection{Pembahasan}

Fokus pembahasan dalam studi ini merupakan sebagai penjelas dari hasil analisis data sebelumnya untuk mengetahui kondisi desa menggunakan nilai variabel dari lima dimensi yang sudah didapat, berikut adalah pemaparannya.

\section{Dimensi Ekonomi}

1. Kegiatan Ekonomi Produktif Variabel kegiatan ekonomi produktif terdiri dari tiga variabel, untuk mudah dalam memahami rendahnya variabel ini berikut gambar dan penjelasannya

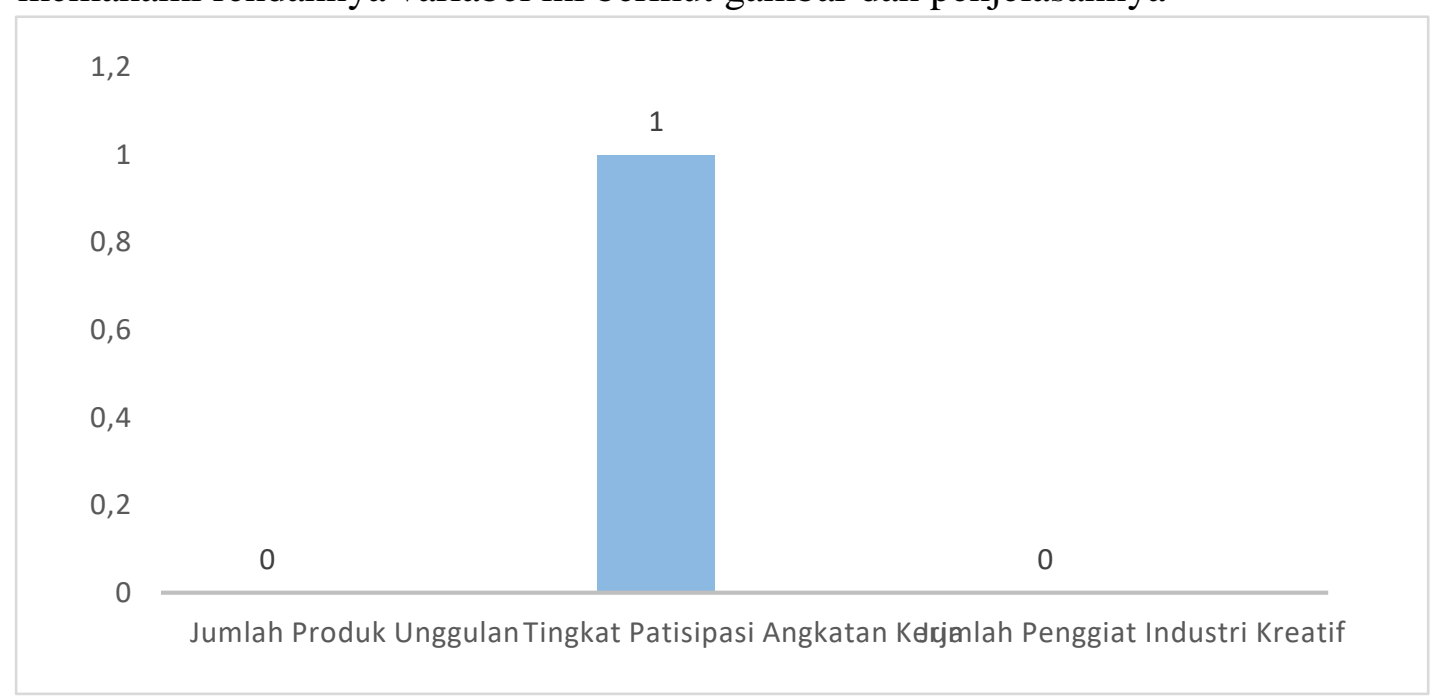

Gambar 1 Nilai Indeks Indikator Kegiatan Ekonomi Produktif

Pada gambar 1, menampakkan bahwa kegiatan industri kreatif pada desa Penambangan sangatlah miris. Karena berdasarkan data angkatan kerja di desa Penambangan tergolong cukup banyak, namun kebanyakan dari mereka lebih 
memilih untuk bekerja dipabrik disekitaran Kecamatan Balongbendo. Sampai saat ini belum ada produk uggulan yang melambangkan desa Penambangan, namun ada beberapa industri rumahan yang memproduksi barang setengah jadi menjadi barang jadi.

2. Pusat Perdagangan Desa

Dalam variabel ini terdiri dari dua indikator yakni pasar dan pusat perdagangan. Sebagaimana teori yang ada, keberadaan pasar dan pusat perdagangan sangat mempengaruhi perekonomian suatu daerah. Adapun nilai indikator penyusun variabel ini bisa dilihat pada gambar berikut.

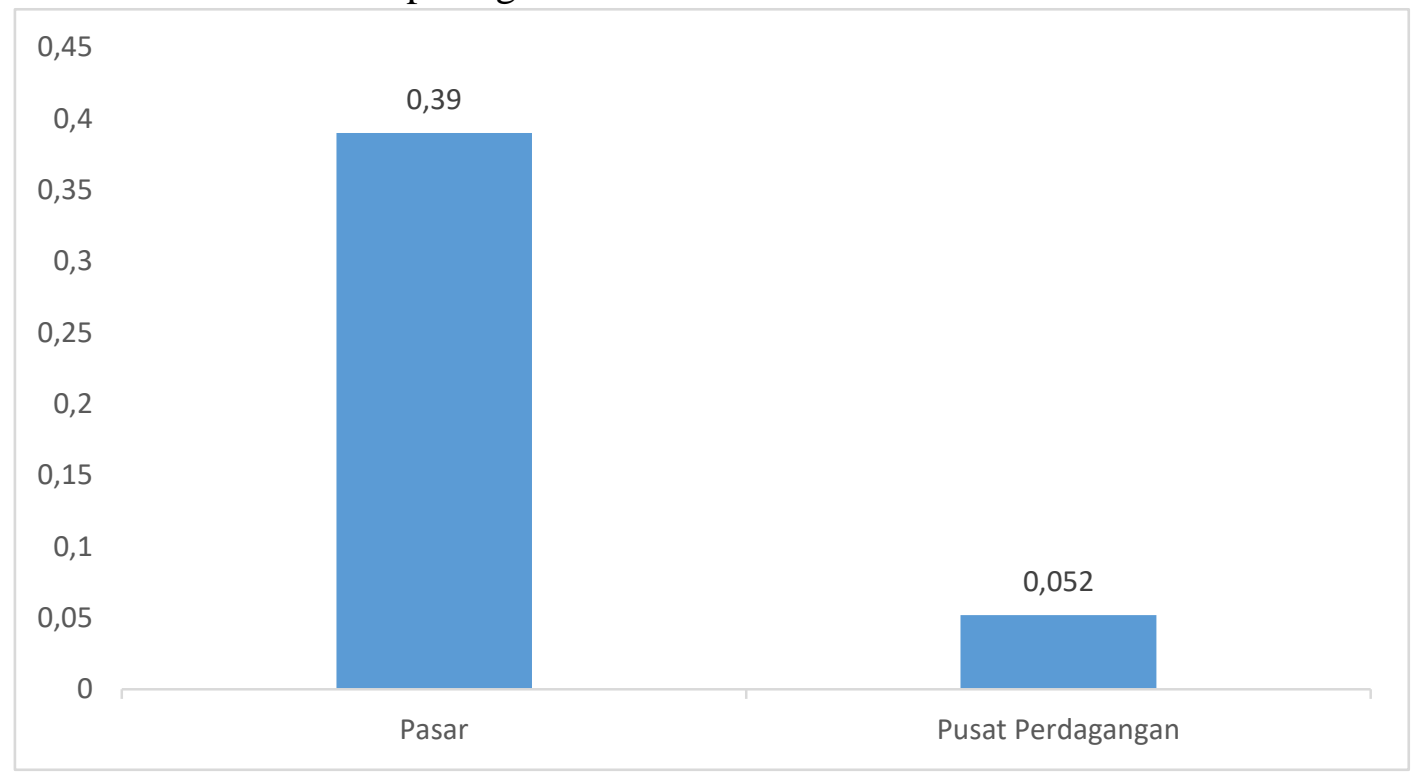

Gambar 2 Nilai Indikator Pusat Perdagangan Desa

Pada gambar 2 di atas menunjukan bahwa kondisi pusat perdagangan yang ada di desa Penambangan kurang baik. Hal ini sangat dipengaruhi oleh indikator pusat perdagangan yang masih minim. Kabar baiknya desa Penambangan sudah mulai membangun pujasera atau sentral Pedagang Kaki Lima (PKL) didekat balai desa Penambangan. Hal ini kedepannya bisa meningkatkan perekonomian desa Penambangan sebagaimana disebutkan sebelumnya.

3. Akses Transportasi dan Jasa Pengiriman

Variabel ini terdiri dari tiga indikator, berikut adalah nilai indeks tiap indikator pada variabel ini, dapat dilihat pada gambar di bawah. 


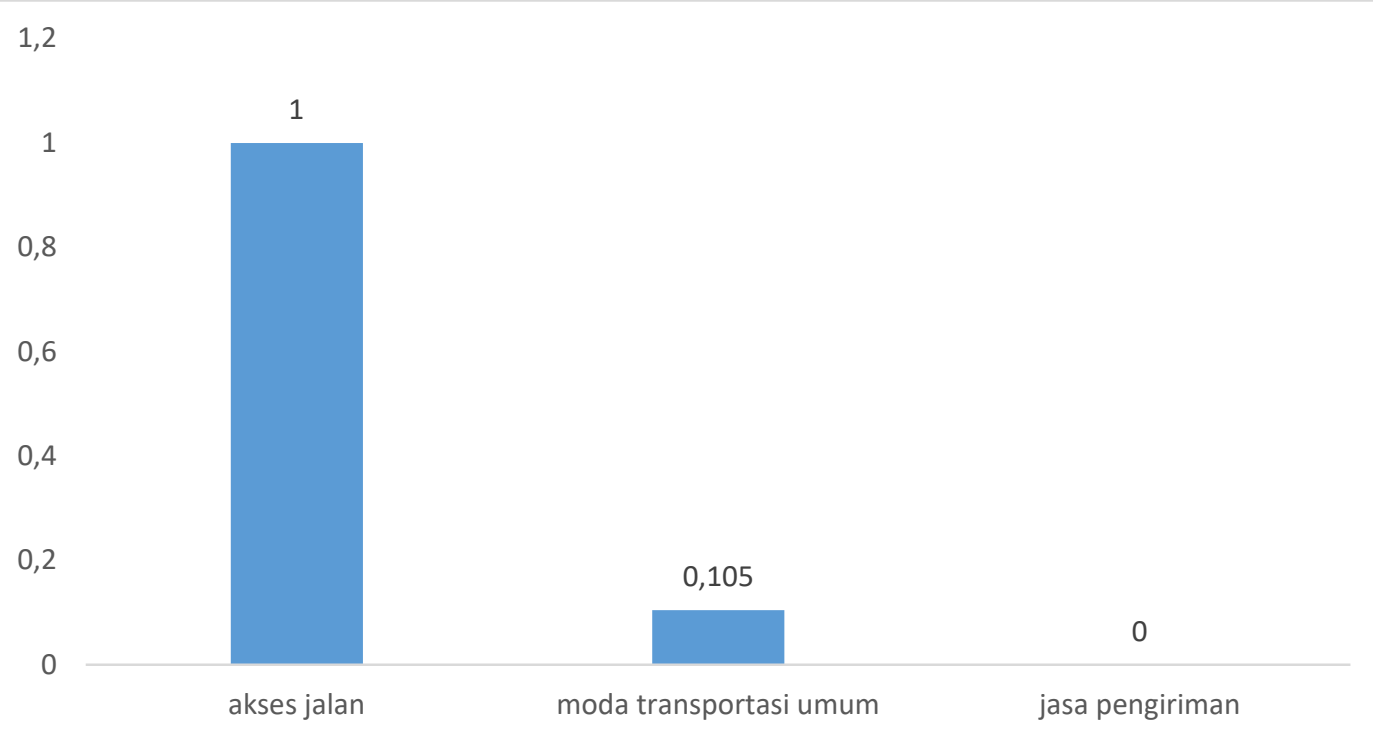

Gambar 3 Nilai Indeks Variabel Akses Transpotasi dan Jasa Pengiriman

Pada gambar 3 nilai indikator pada akses jalan mendapatkan nilai sempurna yakni 1.00 hal ini dikarenakan jalan yang tersedia di desa Penambangan sudah sangat baik dan bisa dilewati kendaraan roda empat maupun lebih dari roda empat. Adapun dua indikator lain masing-masing mendapatkan nilai 0,10 dan 0.00 hal ini dikarenakan berkurangnya transportasi umum yang beroperasi dan akses jasa pengiriman yang jauh dari desa Penambangan.

4. Akses Lembaga Keuangan

Pada variabel ini terdiri dari tiga indikator dan masing-masing nilai pada indikator ini akan dijelaskan pada gambar berikut.

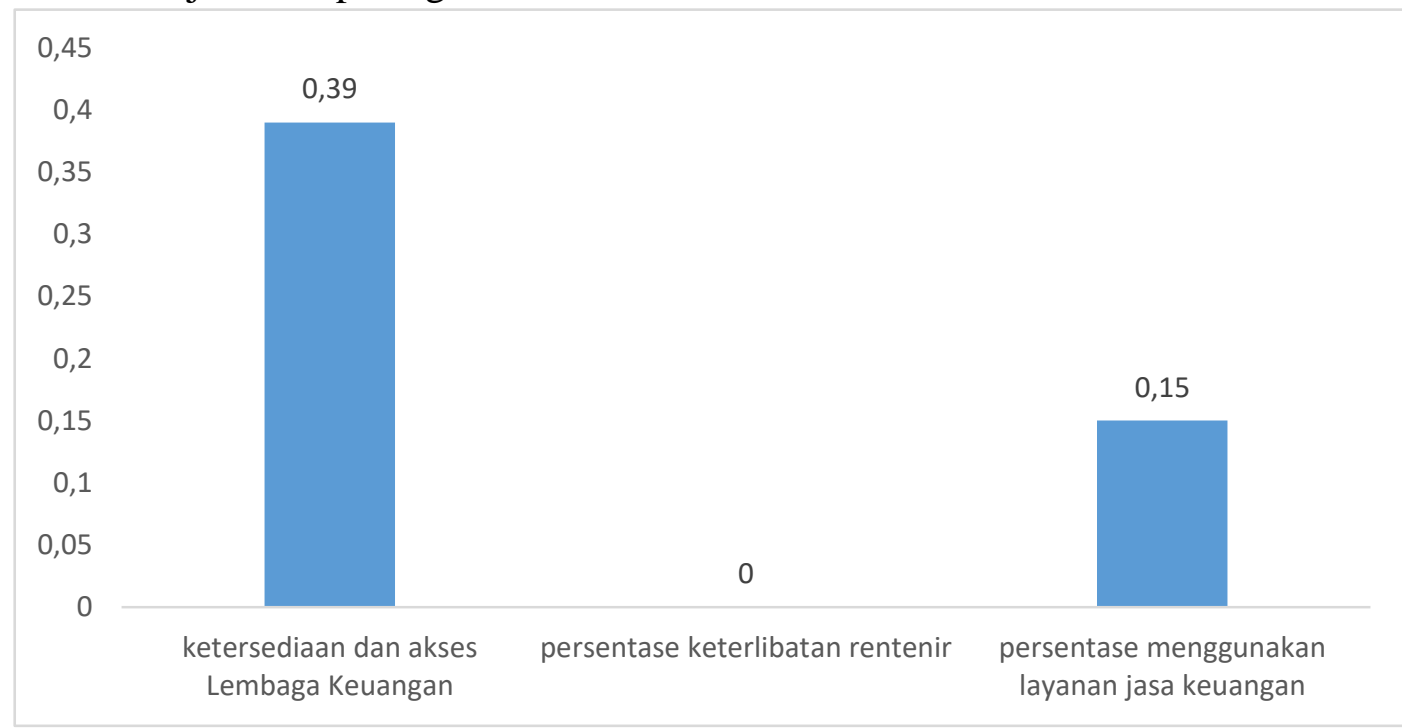

Gambar 4 Akses Lembaga Keuangan

Pada gambar 4, dapat disimpulan bahwa ketersediaan akses lembaga keuangan di Desa Penambanan terbilang cukup baik karena sudah banyak tersedia layananya. Namun pada gambar di atas mendapat skor yang kurang dikarenakan yang mengakses lembaga keuangan modern kebanyakan penduduk yang usianya di bawah 40 tahun. 


\section{Dimensi Kesehatan}

1. Kesehatan Masyarakat

Variabel ini terdiri dari tiga indikator, untuk mengetahui lebih lanjut mengenai kesehatan masyarkat desa Penambangan akan dijelaskan pada gambar berikut.

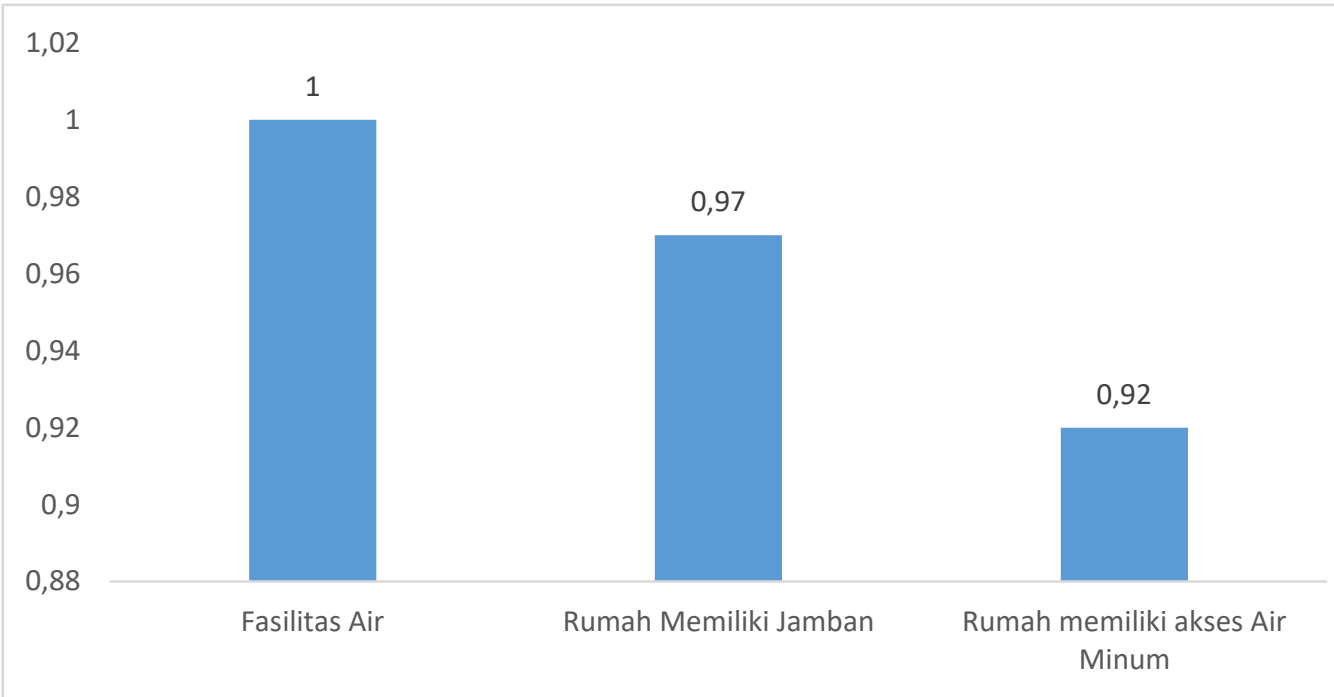

Gambar 5 Nilai Indeks Variabel Kesehatan Masyarakat

Dapat dilihat dari Gambar 5 bahwasanya tingkat kesehatan penduduk desa Penambangan terbilang sangat baik. Dikarenakan prasarana untuk hidup sehat di desa Penambangan sangat mewadai. Adapun untuk sumber air, di desa Penambangan mayoritas penduduknya menggunakan air sumur tidak menggunakan PDAM karena sumber air di desa tersebut masih sangat bersih. Dan untuk tempat buang air besar (WC) pada setiap rumah yang ada di desa Penambangan notabene sudah memiliki semua.

2. Layanan Kesehatan

Pada variabel ini mendapatkan nilai indeks 0,53 yang berarti layanan kesehatan di desa Penambangan terbilang cukup baik. Adapun indikator penyusun variabel ini ada 4, untuk lebih jelasnya akan dipaparkan sebagai berikut.

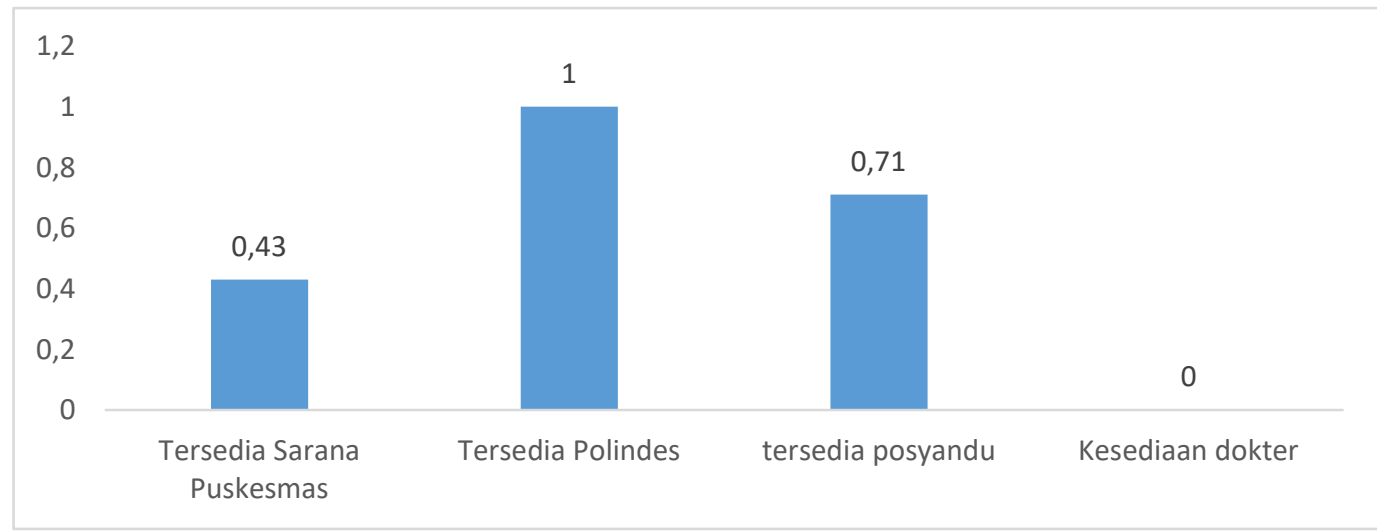

Gambar 6 Nilai Indeks Variabel Layanan Kesehatan

Pada gambar 6 kesedian dokter di desa Penambangan terbilang tidak baik, dikarenakan total dokter praktik (bidan) yang ada di desa Penambangan hanya ada tiga. Sedangkan untuk polindes dan posyandu aktif dilaksanakan setiap dua pekan atau sebulan dua kali. Dan keterjangkauan puskesmas terbilang cukup dekat karena letak geografis desa Penambangan berada pada tengah Kecamatan Balongbendo sehingga dekat dengan Puskesmas. 
3. Jaminan Kesehatan

Variabel ini hanya memiliki satu indikator dan nilai yang didapat pada variabel ini yakni 1.00 sempurna, karena mayoritas pekerjaan penduduk bekerja dipabrik dan mendapatkan jaminan kesehatan dari pabrik, selain itu untuk masyarakat yang wirausaha juga memiliki kesadaran yang tinggi akan pentingnya mengikuti BPJS Kesehatan, untuk penjelasan lebih jelasnya akan dipaparkan sebagai berikut.

Tabel 8 Nilai Indeks Variabel Jaminan Kesehatan

\begin{tabular}{|l|c|}
\hline Indikator & Nilai Indikator \\
\hline Tingkat Kepesertaan BPJS Kesehatan & 1 \\
\hline
\end{tabular}

\section{Dimensi Pendidikan}

1. Pendidikan Masyarakat

Variabel ini tersusun dari dua indikator yakni tingkat pendidikan dan tingkat literasi dari masyarakat, dari dua hal tersebut nantinya akan dapat disimpulkan kondisi pendidikan dari masyarakat. Informasi lebih lanjut akan dipaparkan sebagai berikut.

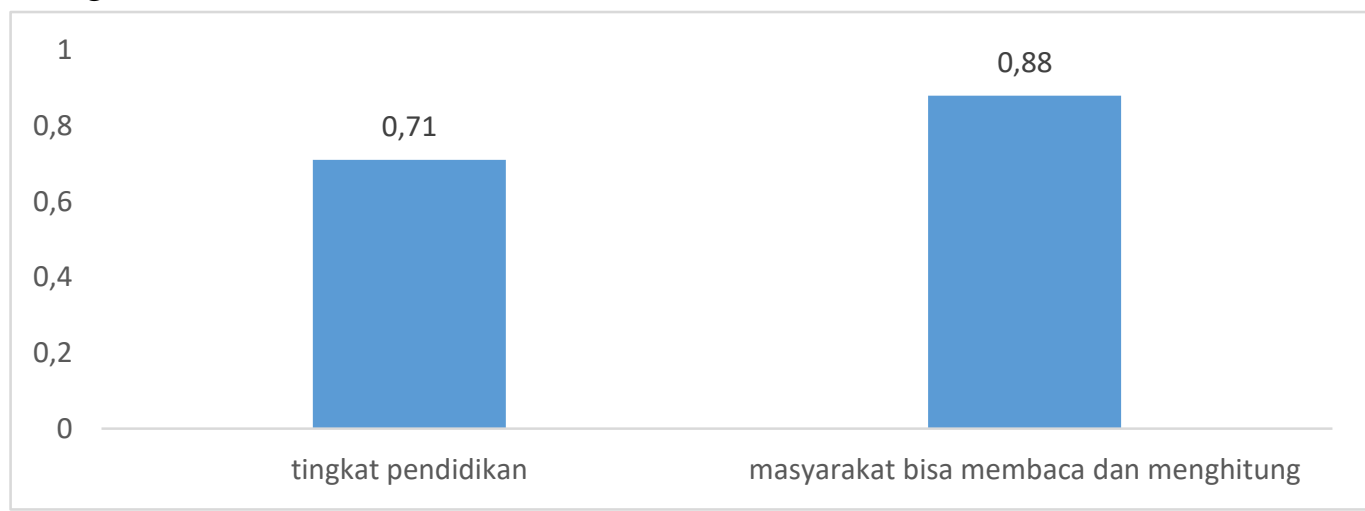

Gambar 7 Nilai Indeks variabel Pendidikan Masyarakat

Pada gambar di atas memaparkan bahwa indikator tingkat pendidikan mendapatkan nilai 0,74 yang artinya baik. Hal ini dikarenakan pada desa Penambangan kesadaran akan pentingnya pendidikan sangat tinggi, berdasarkan data mayoritas penduduk sudah menyeleseikan 12 tahun wajib belajar, walaupun mungkin yang melanjutkan ke perguruan tinggi masih sangat minim. Kemudian membaca dan menghitung masyarakat di desa Penambangan mayoritas dapat membaca dan menghitung.

2. Fasilitas Pendidikan Masyarakat

Berdasarkan Nilai Indeks dimensi pendidikan mendapatkan nilai 0,74 menunjukkan bahwa kondisinya baik, untuk lebih jelasnya sebagai berikut. 


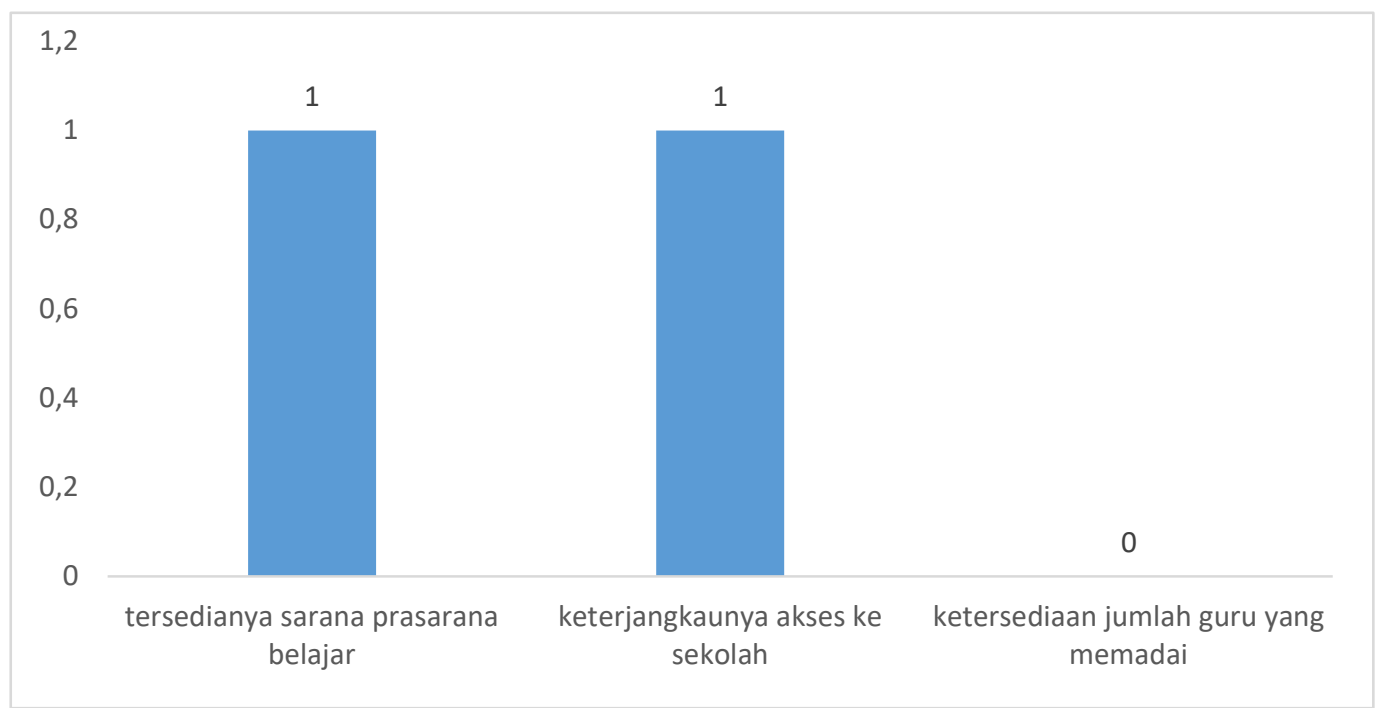

Gambar 8 Nilai Indeks Variabel Fasilitas Pendidikan

Pada gambar 8 menunjukan bahwa fasilitas pendidikan yang ada pada desa Penambangan terbilang sudah sangat baik. Karena jarak sekolah sendiri pun terbilang dekat, untuk tingkat Sekolah Dasar (SD) itu berada didalam desa dan untuk Sekolah Menengah Pertama (SMP) masih terbilang dekat dan tidak lebih dari 5 KM dari rumah. Yang sedikit jauh ada di Sekolah Menengah Atas (SMA) karena berada di luar Kecamatan. Adapun kesediaan guru responden tidak memberikan pendapat dikarenakan kurang mengerti secara detail berapa yang kompeten atau mewadai sehingga enggan untuk menjawab dan akhirnya kebanyakan tidak menjawab.

\section{Dimensi Sosial dan Kemanusiaan}

1. Sarana Ruang Interaksi Terbuka

Variabel ini memiliki dua indikator pembentuk yakni ada sarana olahraga dan kelompok kegiatan warga. Adapun nilai indeks dari dua indikator tersebut akan diapaparkan sebagai berikut.

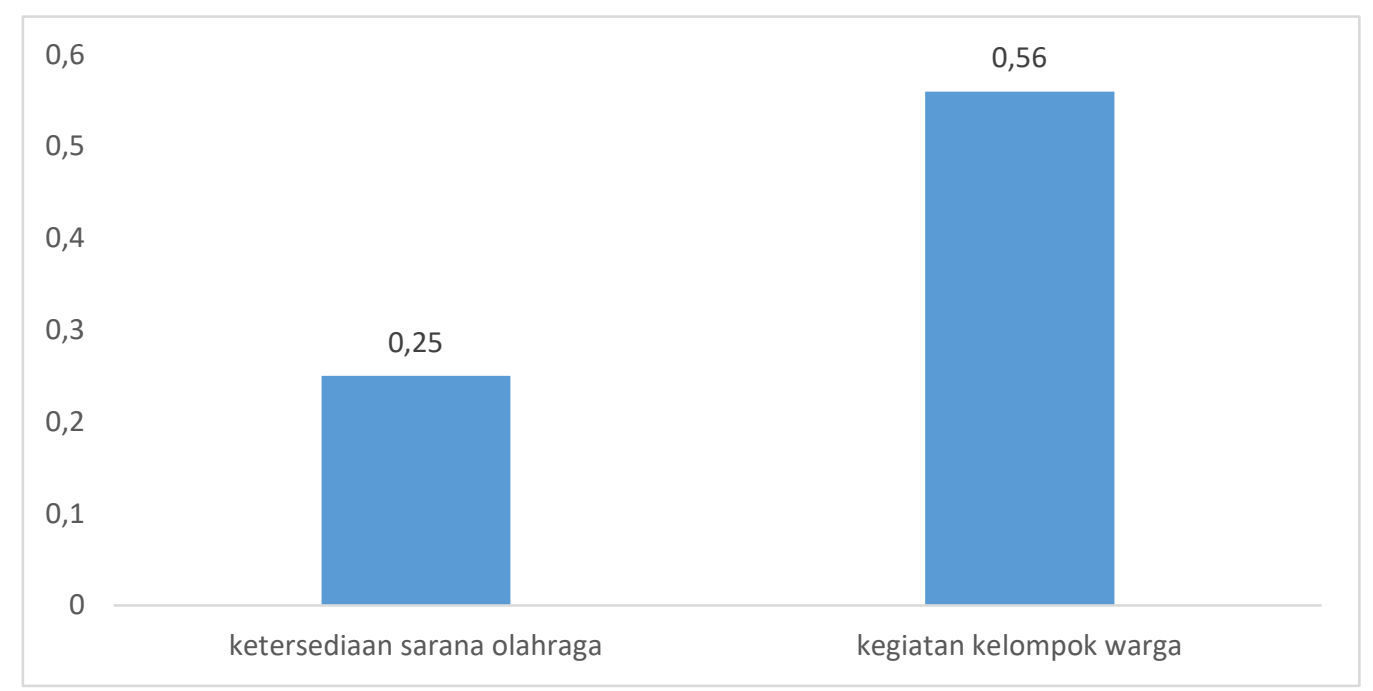

Gambar 9 Nilai Indeks Variabel Ruang Indikator Terbuka

Berdasarkan gambar 9 ketersediaan sarana olahraga kurang baik, karena sarana olahraga yang tersedia masih terbatas hanya ada lapangan bola untuk olahraga lain masih belum ada. Dan untuk kegiatan kelompok warga terbilang cukup 
baik karena kegiatan-kegiatan seperti pengajian, karang taruna, tahlilan masih dipegang teguh oleh masyarakat desa Penambangan.

2. Variabel Infrastruktur Listrik, Komunikasi, dan Informasi

Adanya listrik sangat penting bagi kelangsungan kegiatan warga serta komunikasi dan informasi menjadi parameter dalam IDZ. Karena kedua hal tersebut sangat membantu dalam terlaksananya kegiatan warga. Untuk lebih jelasnya tentang indikator tersebut akan dipaparkan di bawah.

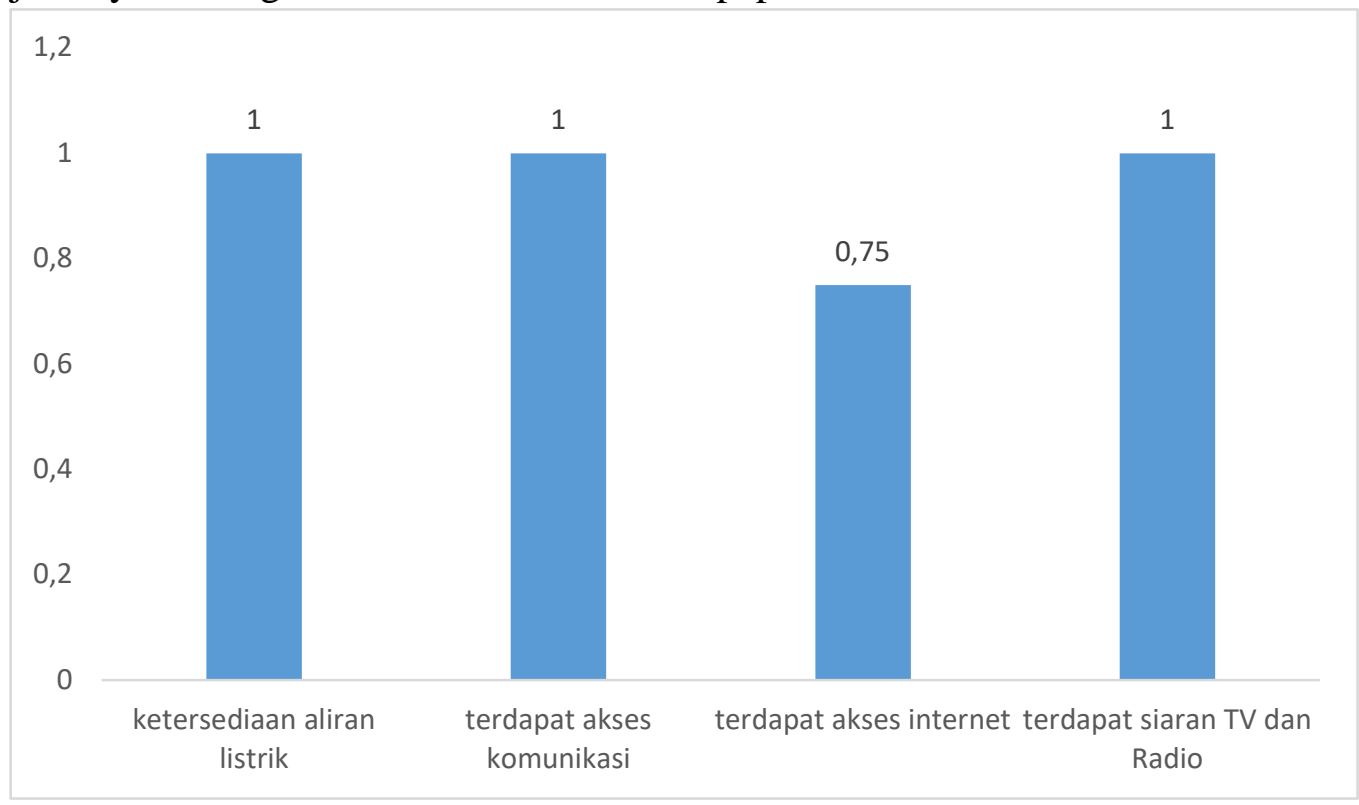

Gambar 10 Nilai Indeks Variabel Infrastruktur Listrik, Komunikasi dan Informasi

Secara keseluruhan jika melihat dari gambar 10 kondisi desa Penambangan dalam variabel ini terbilang sangat baik karena sarana pendukung untuk berlangsungnya kegiatan warga sangat mendukung.

3. Penanggulangan Bencana

Bencana tidak bisa diprediksi kapan datangnya oleh karena itu variabel ini dimasukan kedalam IDZ sebagai bentuk antisipasi kesiapan desa akan datangnya sebuah bencana. Untuk lebih rincinya akan dipaparkan di bawah.

Tabel 9 Nilai Indeks Variabel Penanggulangan Bencana

\begin{tabular}{|l|l|}
\hline Indikator & Nilai Indeks Indikator \\
\hline Penanggulangan Bencana & 0 \\
\hline
\end{tabular}

Tabel 9 menggambarkan kurang baiknya kesiapan desa Penambangan dalam menanggulangi ketika ada bencana. Dikarenakan di desa Penambangan sangat kurang dari segi alat dalam menanggulangi bencana, adapun jika ada informasi darurat perangkat desa Penambangan menggunakan cara klasik dengan menggunakan TOA atau sound mengelilingi desa menggunakan mobil pick up.

\section{Dimensi Dakwah}

1. Tersedianya Sarana Pendamping Keagamaan Variabel ini terdiri atas tiga indikator yakni ketersediaan masjid, akses ke masjid, dan terdapat pendamping keagamaan. Adapun ketersediaan sarana dan pendamping merupakan hal inti yang perlu ada guna untuk mendukung 
masyarakat dalam beribadah. Berikut adalah skor yang didapat dari indikator penyusun dari variabel ini.

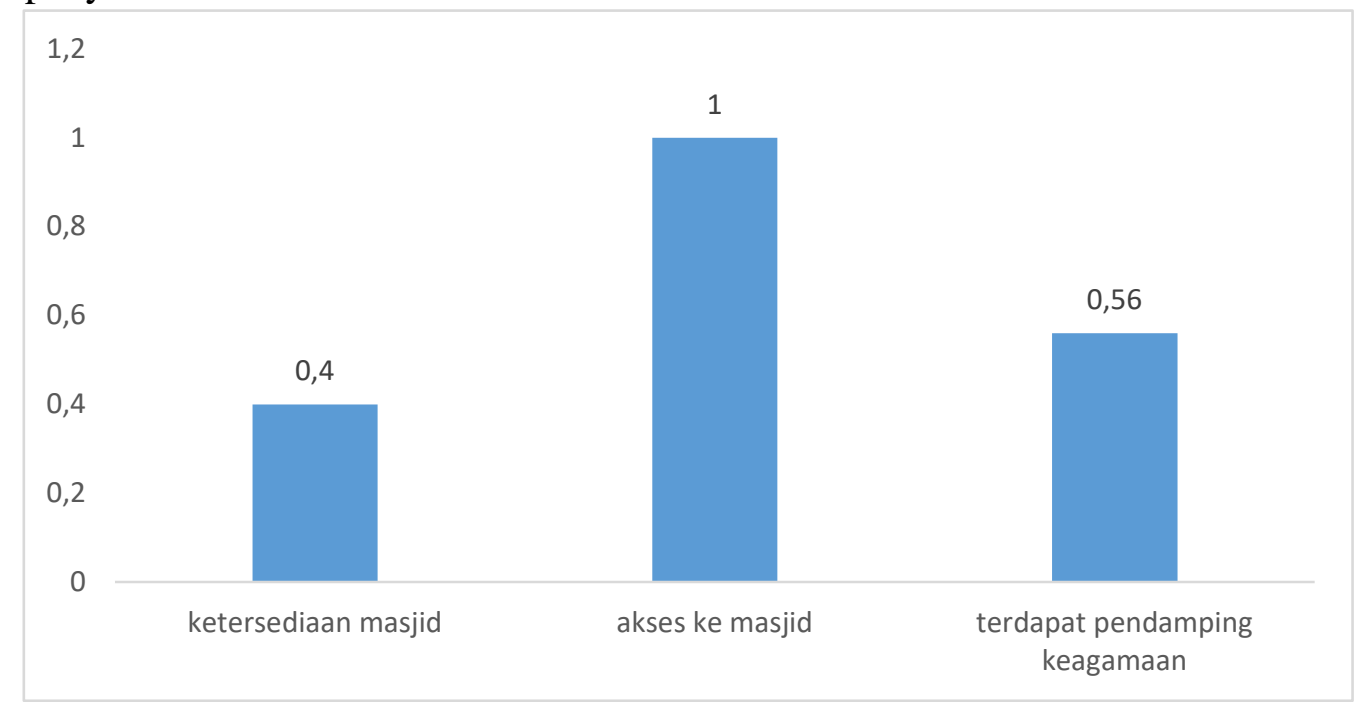

Gambar 11 Nilai Indeks Variabel Sarana dan Pendamping Keagamaan

Berdasarkan gambar 11 ketersediaan masjid di desa Penambangan terbilang cukup baik karena berdasarkan data ada tiga masjid dan dan tujuh musholah yang ada di desa Penambangan. Sedangkan untuk aksesnya sangat dekat tidak lebih dari $1 \mathrm{KM}$ dengan rumah warga. Dan yang terakhir untuk pendamping, setiap masjid memiliki pendamping masing-masing dan cukup mewadai.

2. Tingkat Pengetahuan Agama

Dalam variabel ini terdiri dari dua indikator sebagai penilai yakni tingkat literasi Al-Quran dan Kesadaran dalam membayar Zakat dan Infaq. Berikut adalah penjelasan lebih rincinya.

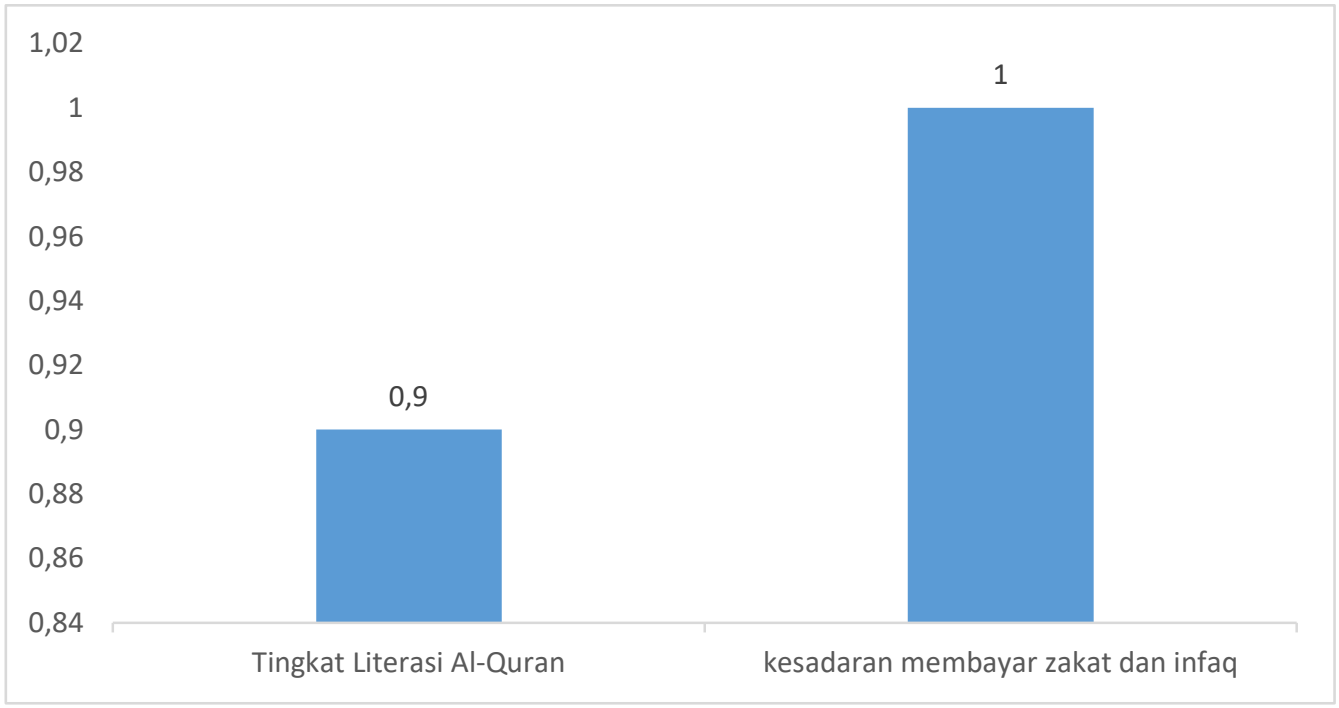

Gambar 12 Nilai Indeks Variabel Tingkat Pengetahuan Agama

Melihat gambar 12 untuk indikator literasi Al-Quran di desa Penambangan terbilang sangat baik dikarenakan kesadaran penduduk akan pentingnya agama sangat tinggi sehingga anak-anak di desa Penambangan selalu dimasukan ke TPQ. Adapun untuk Kesadaran untuk membayar Zakat menurut data terbilang sangat baik karena literasi akan agama sudah terbentuk dari dini.

3. Variabel Tingkat Keaktifan Keagamaan dan Partisipasi Masyarakat 
Dalam variabel ini indikator yang dihitung dari tingkat partisipasi masyarakat dalam mengikuti kegiatan rutin keagamaan dan sholat berjamaah. Untuk informasi lebih lanjut akan dipaparkan berikut.

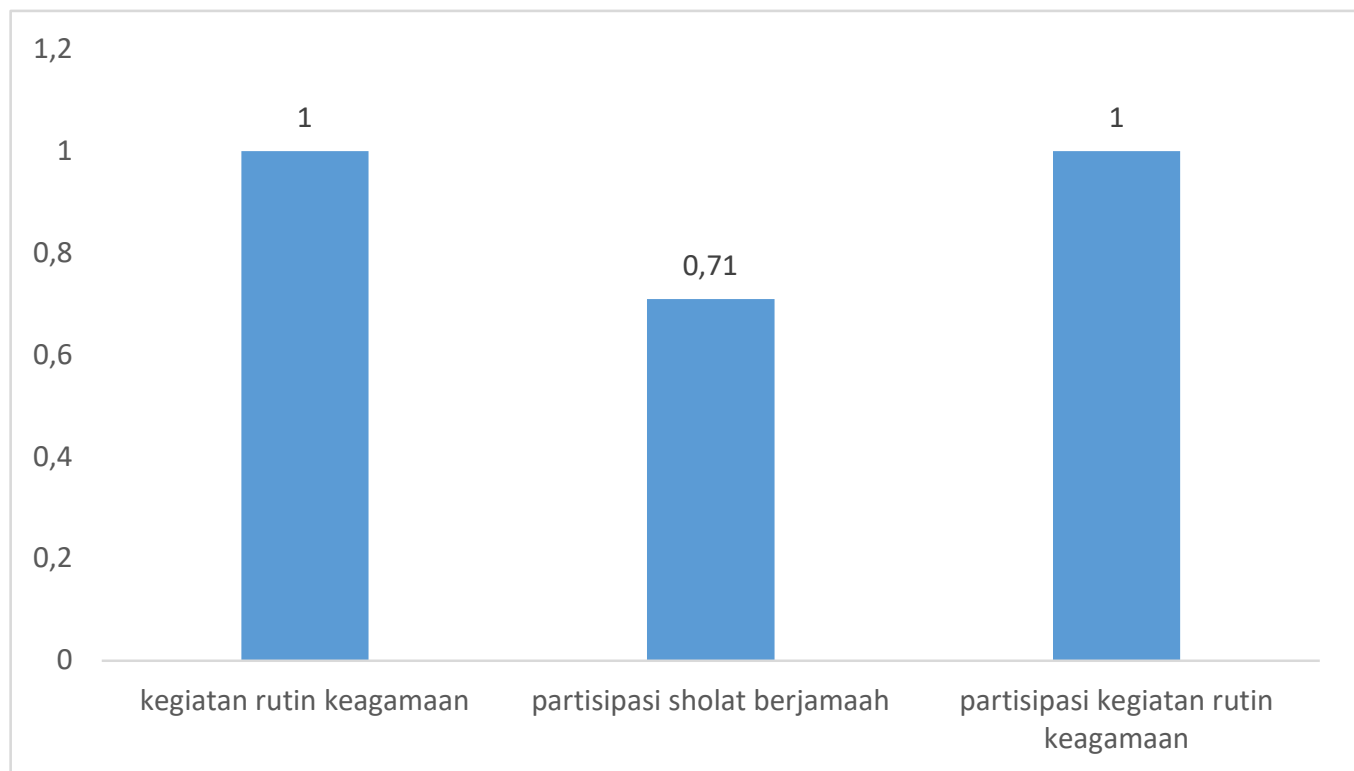

Gambar 13 Nilai Indeks Variabel Variabel Tingkat Keaktifan Keagamaan dan Partisipasi Masyarakat

Berdasarkan gambar 13 kegiatan rutin yang ada di desa Penambangan terjadwal dan terlaksana secara baik. Bahkan menurut beberapa narasumber untuk satu pekannya setidaknya ada dua pengajian rutin. Adapun untuk sholat berjamaah sudah baik, menurut beberapa responden ada waktu-waktu yang sholat berjamaahnya kurang yaitu ketika sholat ashar dan dhuhur dikarenakan penduduk sekitar banyak yang bekerja di pabrik sehingga sholatnya kemungkinan di musholah pabrik. Untuk partisipasi kegiatan rutin sudah sangat baik, dikarenakan kegaitan seperti tahlilan dilaksanakan setelah maghrib sehingga penduduk yang bekerja sudah berada dirumah dan dapat mengikuti kegiatan.

\section{Indeks Desa Zakat}

Dari hasil pembahasan di atas nilai IDZ yang didapat desa Penambangan sebesar 0,65, jika mengacu ke tabel kategori hasil maka Desa Penambangan masuk kedalam kategori desa yang memiliki kondisi baik atau kurang dipreferensikan untuk dibantu. Walaupun begitu tidak menutup kemungkinan desa Penambangan mendapatkan bantuan dana zakat. Berdasarkan penelitian-penelitian sebelumnya desa yang mendapatkan bantuan untuk pengembangan desa membawakan hasil yang cukup signifikan seperti halnya penelitian yang dilakukan oleh Farikhatusholikhah dkk (2018) di desa Bendono menunjukan peningkatan nilai khususnya pada dimensi ekonomi yang memiliki kendala yang sama karena minimnya kegiatan ekonomi produktif. Pada penelitian tersebut menunjukan bahwa pada penelitian pertama skor dimensi ekonomi yang didapat sebesar 22,41 meningkat menjadi 43,03. Adapun jika saja desa Penambangan tidak mendapatkan bantuan pada akhirnya, hal positif yang dapat diambil dan sebagai acuan untuk pembangunan kedepannya agar terfokus untuk mengembangkan sektor ekonomi produktif sebagaimana pada hasil studi ini mendapatkan skor paling kecil. 


\section{Simpulan}

Hasil perhitungan Indeks Desa Zakat (IDZ) secara keseluruhan sebesar 0,651. Angka indeks tersebut berada pada skor antara 0,61-0,80 yaitu berada dalam kondisi baik. Secara indeks skor yang didapat Desa Penambangan kurang dipreferensikan untuk dibantu dana zakat dalam rangka pelaksanaan program Zakat Comunity Development. Hasil yang didapat dimensi Ekonomi sebesar 0,32 yang artinya dipreferensikan untuk dibantu. Kemudian hasil indeks dimensi kesehatan sebesar 0,81 yang berarti kondisi kesehatan masyarakat dalam kondisi baik dan kurang dipreferensikan untuk dibantu. Kemudian hasil dimensi pendidikan 0,74 yang artinya baik dan tidak dipreferensikan dalam menerima bantuan dana zakat. Kemudian hasil indeks dimensi sosial dan kemanusiaan mendapat nilai sebesar 0,55 yang berarti pada kondisi cukup baik dan dipertimbangkan untuk dibantu. Kemudian hasil indeks dimensi dakwah mendapatkan nilai sebesar 0,83 yang artinya dalam kondisi sangat baik dan tidak dipreferensikan untuk dibantu.

Adapun saran yang bisa dipaparkan berdasarkan hasil penelitian pengukuran indeks desa zakat, saran yang bisa diberikan ialah :

1. Dipertimbangkan untuk diberikan bantuan berupa pembinaan mengenai enterpreneur dan pembinaan industri kreatif.

2. Dipertimbangkan untuk diberikan bantuan berupa pendirian taman baca masyarakat, dikarenakan di desa Penambangan tidak ada sarana dan literatur untuk menunjang pendidikan.

3. Dipertimbangkan untuk diberikan bantuan berupa perlengkapan mitigasi bencana alam dan pembinaan megenai pentingnya jalur evakuasi. 


\section{DAFTAR PUSTAKA}

BAPPENAS. 2019. Laporan Kinerja Kementrian PPN/BAPPENAS 2018. Kementrian PPN/BAPPENAS.

BAZNAS. 2013. Zakat Community Development. Jakarta Pusat : Direktorat Jendral Bimbingan Masyarakat Islam

BAZNAS. 2017. Indeks Desa Zakat. Jakarta : Pusat Kajian Strategis BAZNAS

BAZNAS. 2018. Statistik Zakat Nasional 2017. Bagian Liaison dan Pelaporan

BPS. 2016. Jumlah Pegawai Negeri Sipil Menurut Jenis Kelamin dan Kabupaten/Kota. (Online), (https://jatim.bps.go.id/statictable/2017/06/08/429/jumlah-pegawainegeri-sipil-menurut-jenis-kelamin-dan-kabupaten-kota-2016.html), diakses pada 11 Juli 2020

BPS. 2018. Pemeluk Agama Menurut Agama dan Kecamatan, 2018. (Online), (https://sidoarjokab.bps.go.id/dynamictable/2020/03/25/15/pemeluk-agamamenurut-agama-dan-kecamatan-2018.html), diakses pada 11 Juli 2020

BPS. 2020. Persentase Penduduk Miskin di Indonesia. (online), (https://www.bps.go.id/pressrelease/2019/07/15/1629/persentase-penduduk-miskinmaret-2019-sebesar-9-41-persen.html), diakses pada 21 maret 2020

Bunga. A. P., Suhadak. 2019. Uji Beda Ekspor dan Impor Indonesia Sebelum dan Sesudah Terjadi Perang Dagang Amerika Serikat dan China (Studi pada Badan Pusat Statistika Periode September 2017-September 2018). Jurnal Administrasi Bisnis (JAB) Vol. 71 No. 01

Farikhatulsholikhah, Tanti, N., \& Khalifah, M. A. 2018. Implementation of the Zakat Village Index to Support a Zakat Community Development Program in Bendono Village, Demak District. International Journal of Zakat Vol. 3(3).

Jamil, A. 2018. Implementasi Indeks Desa Zakat pada Sungai Desa Kecamatan Rambutan (Untuk Desa yang Terukur dan Berkemajuan). KHOZANA: Jurnal Ekonomi dan Perbankan Islam Vol. 1, No. 2.

Katadata. 2019. Akibat Perang Dagang IMF Turunkan Pertumbuhan Ekonomi Global. (Online), (https://katadata.co.id/berita/2019/10/15/akibat-perang-dagang-imfturunkan-pertumbuhan-ekonomi-global 13 maret 2020), diakses pada 21 maret 2020

Khairunnajah, Irfan, S. B., \& Bagus, S. 2019. Proposing a Zakat Empowerment Program Using IDZ Case Cemplang Village, Bogor, Indonesia. International Journal of Zakat Vol. 4(1).

Magfira dan Thamrin Logawali. 2017. Kesadaran Masyarakat dalam Melakukan Pembayaran Zakat Pertanian Padi di Indonesia di Desa Bontomacinna Kecamatan Gantarang Kabupaten Bulukumba. Makassar. Jurnal Laa Maisyir, Velume 5, Nomer 1.

Maulida, S., Rizali., \& Akhsanul, R. 2018. The Implementation of Indeks Desa Zakat (IDZ) for Priority Areas of the Zakat Community Development (ZCD) Program for 
Empowerment of Productive Mustahiq in South Kalimantan. International Journal of Zakat Vol. 3(3).

Mintarti N. 2011. Pemberdayaan Masyarakat Berbasis Zakat: Model-Model dan Pengukuran Kinerja Program. Executive Development Training Center. Bogor : Institut Pertanian Bogor

Munari Kustanto. 2018. Pemetaan Prioritas Wilayah Intervensi Kebijakan Penanggulangan Kemiskinan di Kabupaten Sidoarjo. Sidoarjo. BAPPEDA Sidoarjo.

Nurul, F, A., A. Jajang W, M., Aas, N. 2019. Implementation of Zakat Village Index (Survey in Binangun Village, Pataruman Sub District, Banjar City). ICIEBP: Sustainability and Socio Economic Growth Volume 2019

Saleh, R., Soleh, N. M. \& Yusuf Wibisono. 2019. Assesment of Zakat Distribution: A Case Study on Zakat Community Development in Bringinsari Village, Sukorejo District, Kendal. Advances in Economic, Business and Management Research, Volume 101

Sangadji, S., Totok. W. A., \& Luluk, F. 2015. Karakteristik Kemiskinan dan Penanggulangannya di Kabupaten Sidoarjo. MIMBAR, Vol 31, No. 2.

Solikatun, Ahmad Zuber, Dkk. 2014. Kemiskinan dalam Pembangunan. Jurnal Analisa Sosiologi Vol. 03 No. 01 Hal: 70-90

Suprayitno E. 2015. Ekonomi Islam: Pendekatan Ekonomi Makro islam dan Konvensional. Yogyakarta : Graha Ilmu

Susilawati, N., Andang, S., \& Rohimin. 2019. Zakat Community Development Program Through a Zakat Village Index Approach. MADANIA JURNAL KAJIAN KEISLAMAN Vol. 23, No. 2.

UNDP. 2017. Human Development Indicators Report. New York: UNDP. (online), (http://hdr.undp.org/en/countries/profiles/IDN) 